\title{
THE SACRAMENT OF THE FIRST CHILD OF GOD: A RENEWED CHRISTIAN ECO-IMAGINARY
}

\author{
Charles J Fensham \\ Systematic Theology \\ University of Toronto
}

\begin{abstract}
The paper argues for reimagining of the narratives of Genesis 1-3 in aid of building a Christian imaginary in Christian communities that will establish an anthropology and cosmological vision supportive of global ecology. It argues that the texts of Genesis 1-2 allow for and give support for the idea that creation itself is a child of God and that God gives birth to creation. Moreover, God cherishes creation in the Sabbath as a newborn. Christian anthropology is thus relativised by its humble status as being part of creation, birthed from God, and by the exposure of human arrogance towards creation in their quest for transcending human limitation. Christian communities can discover new eco-affirming imaginaries in doxological and sacramental celebration of creation.
\end{abstract}

Key Words: Creation, Cosmology, Genesis 1-3, Sacrament, Imaginary

Since the roots of our trouble are so largely religious, the remedy must also be essentially religious, whether we call it that or not. We must rethink and refeel our nature and destiny (White, 1967:1207).

- Lynn White

A metaphor is by definition a calculated category mistake. Yet, at the same time a metaphor provides the power to reveal meaning and the power to motivate when it captures the human imagination. In debates on ecology and eco-theology traditional biblical metaphors for the earth and creation have often been critiqued as supporting the cause for the human destruction of the biosphere. Particularly convincing is Lynn White's landmark 1967 argument in the Journal, Science, where he identifies the Western form of Christianity through its medieval conception as one of the primary causes of the ecological crisis. Even though White's argument has been extensively critiqued, this paper assumes that there is indeed a connection between the metaphors or imaginaries that drive contemporary thinking and human ecological exploitation ${ }^{1}$. The problem is of course much larger than the way Western and Western-influenced Christians think about creation; however, there is still much to be achieved by rethinking and refeeling our nature and destiny. This paper will thus engage some of these critiques, including metaphors of the subjugation of the earth,

See De Steiguer's concise discussion of White's argument and summary of critiques (2006:99-109). 
the metaphor of stewardship, and spiritualising metaphors associated with undervaluing the physical and the earth that still operates in the imaginary of Christian communities. In the midst of these critiques I argue that one metaphor that can be uncovered and employed for the healing of creation is that of creation as child of God. Primarily but not uniquely based in a theological reading of Genesis 1-3, which explores birthing language as well as theological anthropology, this paper will make a case for the earth to be envisaged as a child of God and humankind as care-giving 'grandchildren'. I suggest here that, together with Sally McFague's metaphor or the earth as God's body, creation as child of God provides a powerful sacramental imaginary ${ }^{2}$ for contemporary Christian communities to work towards the wholeness of the earth. In the shaping of imaginaries core metaphors act as fundamental symbols. Addressing the way the story of creation shapes the imaginaries of Christian communities is therefore of fundamental importance.

I argue here that the metaphor of creation as child of God can be related directly to the Genesis creation stories and Christian tradition and is consonant with a birthing sub-theme traced in the texts. The intention is not to provide the metaphor but a metaphor arising out of a reading of the biblical text that is consistent with Christian tradition. To make the case we will begin by examining two case studies that reflect different contextual metaphors for imagining creation.

\section{Two Cases - Some Metaphors:}

\section{Case 1: 'Makoon'3}

In March 2012 a couple driving along the road in Manitoba, Canada, spotted a small bearcub lying in the ditch beside the road. After observing it for a while to see if it moved on, they checked and found a very weak animal weighing only 5 pounds, and clearly not able to care for itself. They rescued the cub and named him Makoon, the Cree word for 'little bear' He was seized two weeks later by Manitoba Conservation, placed temporarily in a zoo, and then released in the wild in June. This last action of Manitoba Conservation caused a furor. The Director for the Society for the Prevention of Cruelty to Animals spoke out strongly against this action because bear-cubs require a much longer time before they are ready to face the wild on their own. In July the SPCA started considering if they could actually prosecute Manitoba Conservation for cruelty to an animal. In defending itself the Mantibo Conservation representative argued that by naming the cub, and by humanizing it, the demonstrations and criticism that erupted was doing more harm than good. He argued that a bear-cub is a wild animal and should not be humanized by giving it a name or imagining it in terms of human experience.

The two visions of Makoon represent us with an example of how different metaphors in Western human imagination may lead to different outcomes in the way humans interact with nature. It provides us with a case study that might help us to consider the different possibilities of differing metaphoric visions of creation. On the one hand is a humanized

I use 'imaginary' here in the sociological sense, which captures the values, institutions and symbols that shape social behaviour as most powerfully expounded by Charles Taylor (2004).

See http://www.cbc.ca/news/canada/manitoba/story/2012/06/13/mb-makoon-bear-protest.html (Accessed

September 12, 2012) 
bear-cub complete with a kind of baptism, and a humanized vision of its relationship with its mother. On the other, a materialized, scientific, and reductionist view of creation, combined with a human stewardship model, which sees it as simply a system with winners and losers with humans as superior judges. Both represent a form of paternalistic and unequal power relationship to creation and its phenomena.

\section{Case 2: My Friend the Mutumbu Tree}

This case is demonstrated in a prayer drawn from Inus Daneel's pioneering African ecomissiology, a prayer by Bishop Marinda at a tree planting ceremony in 1993 in Zimbabwe:

Mwari Father, I have come today to plant your trees. I have come with the mutumbu tree to pay for my transgression [of earth destruction]. I place them here in your soil. You tree, I place you in this soil. Grow! Become tall, wax strong! Even if the hail from the heavens hits you, I want you to remain alive... through the coming ages. My friend whom I love, I shall come to visit often to see you. Stay right here where I plant you Amen (2001:185).

This prayer provides an African Christian liturgical and sacramental vision of creation. Creation is imagined as alive, and sinned against. The planting of the tree becomes a sacramental act of penance, and caring for the tree becomes an act of friendship and brotherhood for the bishop. Creation in this metaphor is imagined, personified, and reenchanted as a 'child of God', not in a literal way, but, in a metaphorical way.

These two case studies demonstrate some of the strength of Lynn White's original premise despite some of the valid critiques. Clearly, behind the two Canadian responses lurks the long Western tradition of paternalism and the exercise of power over creation by humankind. The African example demonstrates an alternative, relational metaphor which moves towards White's original suggestion for a new way to rethink, refeel and, I would add, re-imagine our relationship with creation as being part of rather than powers over creation. In the light of such a reality, we will now turn to a constructive Christian imaginary.

One of my favourite eco-theologies remains Sally McFague's 'The Body of God.' What makes her approach powerful is exactly her profound understanding of the need for a transformative metaphor which can build a new global imaginary in aid of a wholesome relationship between humankind and creation. Even though McFague does not present this as a core argument, her approach also reflects a profound attention to both the Christian Scriptures and tradition. My modest proposal here is to be read in sympathy with McFague's metaphor in the context of her idea of a panentheistic God metaphorically embodied in some way in creation itself. However, I want to suggest a metaphor of relational parenthood of God with creation together with her metaphor of direct organic and agential embodiment. Although I think the sacramental and embodied God metaphor in McFague has great potential, I will argue here that a parent-child relational metaphor arises directly out of the spirit of the biblical narrative. At the very least, it is another metaphor to consider together with the universe-creation as in some way an embodiment of God. 
As White already pointed out in 1967 , one of the thorniest issues we have to face in any Christian ecological metaphor is how to imagine the place and role of humankind in a different way from the traditional, medieval and later enlightenment, industrial and consumer metaphor of exploitation and subjugation. The convergence of a simplistic and self-serving reading of Genesis 1:27 and the agenda of a mechanistic and consumer driven view of creation has been the bane of Christian theology over the last three centuries. The human 'come of age', Kant's so called 'enlightenment', turned out to be anything but enlightened, but rather a kind of destructive self-focused indulgence and arrogance. Rightly so, ecologists and eco-theologians critique the assumption of the human at the centre while in reality we know that we are but stardust - part of creation - truly adam (earth) of the adama (earth) as Genesis 2 reminds us. The attitude reflected by the Conservation authority of Saskatchewan can be firmly fitted into the Enlightenment-Industrial-Scientific mindset and it illustrates why the eco-critique is so necessary. Even though it appears that 'conservation' is the aim, what it really does is reduce creation to an object of human dominance and expediency.

As McFague so perceptively points out, our technological power and our unbridled philosophies of growth, have placed us in a central role despite our truly humble origin and place. We can destroy the earth and we are fast doing it. How do we thus recognise this power and its danger and the need to stop it without again putting ourselves in the centre? McFague correctly calls this a 'curious reversal' of human importance (1993:108). Her response is to suggest a combination of traditional organic and agential metaphors to imagine the relationship between humankind and creation. She shows convincingly how these metaphors are helpful and faithful to Christian tradition and Scripture, but also, how, like any metaphor they also hold inherent limitations. As we proceed now to explore the possibilities of the creation as a 'child of God' metaphor, we would do well to keep these same strengths and limitations of metaphors in mind. Below I will make the case for this metaphor by looking at the Hebrew Bible, discussing alternative readings of the text, examining some of the unhelpful ways in which the text functioned in relation to creation, and by proposing a new imaginary way for Christian communities to read the text in the light of sacramental practice.

"Bereshit bara Elohim et hashamayim ve'et ha'arets." - "In the beginning God created the heavens and the earth", thus reads the opening words of the Hebrew Scriptures. The late Adrianus van Selms, in his commentary on the Book of Genesis, hints that we could read these poetic opening words as, "In the time before time began God gave birth to the heavens and the earth." As a Semitic scholar, Van Selms was aware that bara was a word commonly used for act of building, and was also used for the act of giving birth by one South Arabian tribe, while more commonly, bara became associated with the bringing forth of descendents (1967:20). ${ }^{4}$ While it is important to note commentators who insist that bara should only be read and limited by the semantic value of this word in the rest of the biblical

4 It has to be recognized here that Van Selms' commentary is dated and that not many other commentators have supported this reading of bara; however, what Van Selms' observation of one potential parallel of reading of bara opens up for us is the possibility of imagining this text in a different way in addition to the more accepted readings of the text. If we combine this with some of the Old Testament texts that more directly uses birthing and 'begetting' metaphors for creation (e.g. Psalm 90:2 'to bring forth' and Deut. 32:18 'birth') it makes such a theological reading possible. 
text, we should recognise that there are obvious birthing metaphors inherent in the Genesis 1 text juxtaposed with it, including the brooding of the female Spirit over the waters or seed $^{5}$. In addition, the great refrain, "and God saw that it was good" (tov), ${ }^{6}$ is paralleled in the Exodus 2:2 account of the birth of Moses which echoes the Genesis 1 refrain but associates a generative birthing image.

If we were thus to read the Scriptures as inviting us to hear that God could also be imagined as birthing Mother of the cosmos, complete with brooding and seed, and possibly womb, then creation in its most fundamental form is something brought forth from God and finding its purpose in this relationship. Not only does God give birth, but the Genesis creation stories also imply the cherishment of creation as a mother cradles a new-born child. What else is the shabbat of God, but the very picture of God cradling, cherishing and admiring creation? The act of setting aside and blessing described in Genesis 2, is the celebratory active rest of shabbat. The blessing and hallowing of time can be understood as and act of blessing all of creation as coming forth within time. The great refrain of the Genesis 1 poem, is, "and God saw that it was good", and it is perhaps not by accident that the act of seeing raha rimes beautifully with bara. To give birth then becomes to see - to behold - to cherish the goodness. On the shabbat God rests from the labour of child-birth. The shabbat thus suggests an agential parental indulgence of creation (not just the human), and even as creation is dynamic, developing and growing with fecundity, so does the parental agent stand in relation, in care, and in loving concern.

The Kabbalistic doctrine of the Divine withdrawal or constriction, which is known as tzimtzum (Wyschogrod, 1996:313), argues that God had to withdraw or limit God-self to make room for the coming forth of creation. Moltmann points out that Isaac Luria, who developed this idea, built it on the Hebrew conception of the divine indwelling in the temple as manifested by the shekinah of God (1985:87). Luria expands this idea to cosmology and the creation of mystic primordial space in which creation comes into being. Thus, God makes space for God's cherished offspring - creation. Not just humankind, but the whole of creation, becomes the other to God and thus stands in relationship within such primordial space. The act of giving birth is exactly the act of giving up and of making room for another in an organic way through the room made by the womb. Yet birthing, which emerges from such womblike primordial space, is not a giving away or a complete letting go. Even though the idea of tzimtzum speaks of making room as represented in the purposive refrain, "let there be", it is not a mechanistic image or an abstract conception - it is a concrete relational space that is being made. Birthing implies mutuality, interaction, and a commitment to mutual love and care. The repeated refrain "Let there be" suggests a metaphor of relational room-making or ceding of space.

Consider how holding and cherishing a newborn child in our arms and looking into their eyes, evokes the visceral and poetic power of this alternative relational reading of the

\footnotetext{
See Wenham discussion of the alternative reading of this text where hovering, in the light of Syriac (rahep), is read as brooding and the reference to the other example of the use of rachaph in Deuteronomy 31:11. Even though Wenham considers the 'brooding' reading as unlikely, we can note the 'motherly' dimensions to this metaphor of the Spirit 'hovering-brooding' over the waters. It is therefore possible to imagine a link between the waters of the womb and this imagery (Wenham, 1987:17).

6 Of course Hebrew, 'tov' carries with it a wider meaning than just simply good, it particularly identifies good quality and fitness for purpose (Wenham, 1987:18).
} 
creation story? It is the act of seeing, cherishing and declaring what is obvious, 'it' - 'she' 'he' is good and right (tov). This fundamental and generative relational perspective on God and creation is the first element I would like us to note in this argument. Thus, I submit that a metaphor which conceives of God's bearing forth of creation is a powerful and imaginative way to understand the humble place of humankind in the greater birthing event of creation. Genesis in this sense is the genesis of the Mission of God to bring forth and create and to stand in agential parental loving relationship with creation as a whole, and the clues dwell in the text itself.

Some Hebrew Bible scholars have pointed out that the structure of the Genesis 1 poem is in some ways similar to the structure of a covenant between a vassal and a king (Niehaus, 1995:145-146). Of course, such covenantal structure would suggest the possibility of power over and exploitation. Nevertheless, the covenantal dimensions of the text do not, necessarily, negate the possibility of reading the poetic reference to birthing. In fact, such a metaphoric perspective moderates the ideas of power over and exploitation suggested by the idea of 'subjugation' (kabash) in Genesis 1:28. If we read the story by noting the birthgiving and room making references, and I propose that we should, then the importance of creation and the peril of the earth in our time take on profound theological meaning.

This relational metaphor also makes strong sense in the light of the long Hebrew and Christian tradition of conceiving of God as in engaged agential relationship with creation (McFague, 1993:139-142). Just as McFague stresses that these metaphors present perspectives with limitations, so the birthing and childhood metaphor also has limitations. In fact it is exactly the limitations, and problems raised by any human metaphor (including the inevitable anthropomorphising of God) that makes it a metaphor - a calculated category mistake. Yet, an imaginary that can conceive, worship, and relate to a Divine Being who graciously makes room, admires, cherishes, and is relationally tied to creation as a whole, could inspire Christian communities to think of themselves as a humble part of that larger loved and cherished offspring of God. Such a perspective does not exhaust the description of the relationship between God and creation, but rather, enriches the many other metaphors. Such an imaginary also invites us to re-imagine Christian anthropology in a more humble way, a theme to which we now turn.

The persuasive ecological critique is that Genesis 1:26-28 - the covenant of human stewardship of creation - is at the root of our present destruction of the biosphere. We have to admit that the language of this text is extraordinarily strong. The words used there seem to state that humans are to fill the earth with descendents; they are to conquer and subjugate or have dominion over the earth. What is this other than a carte blanche for a population explosion, and a robber baron approach to earth's resources and biosphere? If we look at the early medieval developments, the enlightenment and colonial history of Europe and the Americas, the impact of the Industrial Revolution and presently the impact of global carbon emissions, deforestation and pollution we can only conclude that such an ecological critique has to be taken with utmost seriousness. Is it then simply naïve to attempt to find a more wholesome metaphor in this ancient mythic story? I suggest here that it is exactly because of the power of this text in history that we need to re-read the Genesis creation stories with new eyes. For one thing these stories still function powerfully in many Christian communities around the world. These communities remain traditioned by the 
Genesis narratives, and, how they read and understand these stories become of critical importance. The possibility and the reality of appropriating these stories, around the globe in the growing Christian movement, in the way of the $19^{\text {th }}$ and $20^{\text {th }}$ century, remain strong. Within Christian communities we need a new vision, new eyes and a new enchantment of the creation story to inspire us in action, liturgy and prayer so that we may relate differently to creation. Such a fresh appropriation must also relate to the text with integrity.

Jürgen Moltmann invites us to read these texts with attention to their cultural setting and the evolution of reading them over time. He argues that the origin of these Genesis texts, which goes back more than 3000 years, can hardly be blamed for the relatively recent developments in science and technology. In fact, he shows that it is in the Renaissance and in nominalism that we see the rise of the emphasis on God's absolute power as the preeminent attribute of God's divinity (1985:26). Moreover, it is to Francis Bacon and Renee Descartes that we can trace the emphasis on human dominance, and we have to add particularly the human male's role as "maitres et possessuers de la nature" (1985:27). Many have shown that one of the basic attributes of the enlightenment movement has been the process of objectification of nature. In addition, the enlightenment tended to create a dualism between the focus of theology on history while leaving nature to the sciences (Moltmann, 1985:31). Lynn White has also pointed to the genesis of these ideas in earlier technological developments in the medieval period (1967:1204-1206).

Our Genesis texts arise in a culture and time where subjugation by technology was simply unimaginable. Moltmann persuasively points out that the Genesis 1:26-28 text places the human in correspondence with God the creator and preserver of creation. ${ }^{7}$ Such a correspondence clearly advocates against an anthropocentric reading of this text. I would add that this is a point even more poignant if we read it in the light of the suggestion here of a metaphor of God giving birth to creation which relativises human power even more. In addition, Moltmann argues that the second Yahwistic creation account in Genesis 2:15 places the language of domination in the context of agricultural responsibility (1985:30). If the language of Genesis 1:26-28 also implies to some degree the language of a covenant between a vassal and a king. There is also a radical and potentially fatal accountability between the human who holds dominion as a vassal on behalf of God and God. The vassalking covenantal language of this text is well known to the point that it is often taken as the first covenant between God and humans in covenantal theology (for example see Von Rad, 1962:301-324). This insight into the humble and accountable covenantal place of the human within God's creation is critical for a re-conception of the "curious reversal of human importance" (McFague) in relation to creation. If creation is conceived as a kind of child of God, then humans who are of this child are at best 'grandchildren.' Humans are of the earth, of the offspring and not masters and possessors. Humans are offspring of a kind with accountability and responsibility and above all, a humble place within the cherished creation.

So, what to do then with the paradoxical power of humankind to kill, harm, and destroy creation, developed in the Western trajectory of technology and science, despite the actual

See also Fretheim's interesting discussion of the need to emphasise the way God is depicted in the Genesis 1 creation account to unpack what 'image of God' might mean for the human (Fretheim, 2005:48ff.). 
humble origin we have in relation to creation? I submit here that we have to deal with this within Christian tradition by means of the story of Genesis 3, and particularly from the point of view of theological anthropology. In Genesis 3 the brokenness of creation is introduced and it is clear that it is human brokenness. Especially from our contemporary vantage point we can see that something has gone deeply awry in creation. With our planet literally in human induced ${ }^{8}$ peril, with war, genocide, and pollution a daily fact, and with technology that holds both promise and destructive potential, brokenness is self-evident. So far have things gone that James Lovelock, the originator of a re-emergence of Gaia language for the earth, has reached the point of despair and now invites us to plan for disaster, rather than work for healing (2006). What is striking in the story of human failure is God's cry of agony as represented in Genesis 3:9. In the Hebrew a whole sentence is simply contained in one word, 'where?' (Ahee) (Fensham, 2011:170). Implied in this Divine agony over the folly of humankind is a commentary on a kind of parental relationship between God and creation explored above. This agonising call echoes through the scriptural text right to the agony of Christ on the cross, "My God, my God why have you forsaken me?" This mutual forsakenness of the creator and creature - parent and (grand)child, through human arrogance and creation destruction holds tremendous pathos. Implied in this Divine appeal for human response, lies the heart of our mission as human beings in response to the greater mission of God's acts of birthing creation and sustaining and healing it. Our mission, as rooted in Genesis 3:9, begins with God calling out to us humankind - who has become the abusive vassal destroyer of creation, to invite us back. Returning to, and embracing our humble place and our limitation within creation as creatures, is in essence what is meant by the theological concept 'repentance'. It is this repentant humility that qualifies Christian anthropology.

The arrogance of humans striving to transcend their humble place as creatures and children and attempting to become gods lies at the heart of God's agonising call to return. This arrogance takes on the shape of the human as 'come of age' or as 'scientist' without moral and ethical limits and responsibilities. The text metaphorically expresses the folly of such a technological human solution in the covering of shame with leaves (Genesis 3:7). The social destruction that follows manifests in blaming each other for destructive behaviour. In fact, McFague points out that ' $\sin$ ' at its heart is the human attempt to not accept human limitation (McFague, 1993:175). Karl Barth's theological anthropology, as developed in CD III, 2, echoes this perspective as he argues that to be human is to accept our humble limitation as creatures before God. Barth expresses it this way, "Hence his (sic) going to God, his (sic) responsibility before Him (sic), must be of such a kind as to realise and express his (sic) limitation (1975:189)." The stewardship model, which has often been employed in Christian tradition to engage the ecological debate runs a huge risk of being stewardship in deploying human technological fixes. The dimension that can move beyond this kind of arrogant human stewardship of creation is the acceptance of such humble limitation. Only where this radical anthropological limitation is embraced as part of responsibility will we be able to speak constructively of stewardship within God's covenantal relationship with humankind. Any other form of stewardship will lead to further damage by means of human arrogance. An excellent attempt at doing this has been Douglas

It is outside the scope of this paper to deal with questions of natural suffering and destruction in creation. 
Hall's project of developing limitational responsibility into a full-fledged theology of stewardship $(1982,1985,1986)$. In the language and culture of the ancient Near-East, we can say we are humble and limited vassals responsible to God for the destruction of the 'land' we are part of and to in relationship with which we have to live. Re-imagining creation as a child of God requires re-imagining humankind in a radically humble yet powerful place within creation.

Metaphors and symbols only gain power as imaginaries if institutionalised in some way in culture. For Christian communities traditioned by the texts of Genesis 1-3, such institutionalisation occurs in the context and by means of doxology and sacrament. The metaphor of creation as child of God has thus to be sacramentalised. As child of God creation is a visible sign of God's grace. Understanding creation as sacrament is by no means a new idea. However, as McFague points out, this sacralising of the world in Christian tradition is usually transmuted in a spiritualising process that ultimately undervalues the reality of physical things (1993:182-184). In response she suggests that we need to move away from a utilitarian view of creation as sacrament as well as an identification of embodiment with sin (1993:185). Indeed, sin, as my argument above suggests, is exactly the opposite of the traditional disembodied concept of redemption. It is the disembodiment of humankind in the arrogant quest for transcendence that leads to the destruction of creation as a child of God. When we recognise plants, animals, rocks, stars, and even our human bodies as 'god-child' and therefore part of God - albeit 'visible rearward parts of God'(Martin Luther in Lull, 2005:49) - then we can come from East and West, from North and South and sit at table with the crows, the bears, the granite and the carbon creatures. When our hymns can sing this, our dreams can dream this, and our chalices hold this, then may we imagine and live for a whole creation. As Bishop Marinda so beautifully and sacramentally put it to the mutumbu tree - child of God and friend, "My friend whom I love, I shall come to visit often to see you. Stay right here where I plant you (2001:185)."

\section{BIBLIOGRAPHY}

Barth, K 1975. Church Dogmatics III, 2. Translated by Bromiley, GW Edinburgh: T\&T Clarke.

Daneel, ML 2001. African Earthkeepers: Wholistic Interfaith Mission. New York: Orbis Books.

De Steiguer, JE 2006 The Origins of Modern Environmental Thought. Tucson: University of Arizona Press.

Fensham, CJ 2011. Emerging from the Dark Age Ahead: The Future of the North American Church. Toronto: Clements Academic.

Fretheim, T 2005. God and World in the Old Testament: A Relational Theology of Creation. Nashville: Abingdon Press.

Hall, DJ 1982. Steward: A Biblical Symbol Come of Age. New York: Friendship Press. 
1985. The Stewardship of Life in the Kingdom of Death. Grand Rapids: Eerdmans. 1986. Imagining God: Dominion as Stewardship. Grand Rapids: Eerdmans.

Lovelock, J 2006. The Revenge of Gaia: Why the Earth is Fighting Back and How We can still Save Humanity. Santa Barbara: Allen Lane.

Lull, T (ed.) 2005. Martin Luther's Basic Theological Writings. Philadelphia: Augsburg Fortress Press.

McFague, S 1993. The Body of God: An Ecological Theology. Minneapolis: Fortress Press.

Moltmann, J 1985. God in Creation: A New Theology of Creation and the Spirit of God. New York: Harper \& Row Publishers.

Niehaus, JJ 1995. God at Sinai: Covenant and Theophany in the Bible and Ancient Near East. Grand Rapids: Zondervan.

Taylor, C 2004. Modern Social Imaginaries. Durham: Duke University Press.

Van Selms, A 1967. De Prediking van het Oude Testament: Genesis deel I. Nijkerk: Uitgeverij GF Callenbach

Von Rad, G 1962. Old Testament Theology 2 vols; New York: Harper \& Row Publishers.

White, LT 1967 'The Historical Roots of Our Ecologic Crisis’ Science 155:3767 (March 10), 1203-1207.

Wenham, GJ 1987. Word Biblical Commentary: Genesis 1-15. Nashville: Thomas Nelson.

Wyschogrod, E 1996. 'Hasidism, Hellenism, Holocaust: A Postmodern View' in Interpreting Judaism in a Post Modern Age. Kepnes, S (ed.) New York: New York University Press. 301-324. 